\title{
LOCAL PROPERTY AND STATE INCOME \\ TAXES: THE ROLE OF \\ INTERJURISDICTIONAL COMPETITION \\ AND COLLUSION
}

Thomas J. Nechyba

Working Paper 5419

\author{
NATIONAL BUREAU OF ECONOMIC RESEARCH \\ 1050 Massachusetts Avenue \\ Cambridge, MA 02138 \\ January 1996
}

I am grateful to Marcus Berliant and Hideo Konishi for helpful comments and discussions, to Nathan Hatch for his assistance with SAS, to Robert Strauss for his insights and the generous use of his VAX computer and to William T. Bogart for providing the New Jersey data set used in calibrating the computable general equilibrium model. The paper has benefitted from the comments and discussions at seminars at the University of Rochester, Stanford University, Caltech, UCLA, UCSD, Indiana University, Texas A\&M, Brown University, Washington University in St. Louis and the Federal Reserve Bank in Atlanta. All remaining errors are, of course, mine. This paper is part of NBER's research program in Public Economics. Any opinions expressed are those of the author and not those of the National Bureau of Economic Research.

( 1996 by Thomas J. Nechyba. All rights reserved. Short sections of text, not to exceed two paragraphs, may be quoted without explicit permission provided that full credit, including () notice, is given to the source. 


\title{
LOCAL PROPERTY AND STATE INCOME \\ TAXES: THE ROLE OF \\ INTERJURISDICTIONAL COMPETITION \\ AND COLLUSION
}

\begin{abstract}
This paper attempts to address two long standing positive questions in Public Finance: (i) why is the property tax, despite widespread popular complaints against its fairness, the almost exclusive tax instrument used by local governments, and (ii) why do we consistently observe higher levels of governments (states) undermine local property tax systems through income tax funded grants and state imposed caps on local property tax rates. A new intuitive argument to explain (i) is presented and tested in general equilibrium simulations. These simulations utilize a computable general equilibrium model of local public finance with parameters set to be consistent with micro-tax data. Different types of agents are endowed with income and houses and are able to move to their most preferred house in their most preferred jurisdiction. Furthermore, agents vote myopically on local property tax rates (and local public good levels), while non-myopic community planners set a local income tax. Six possible objective functions for community planners are postulated, and all six lead to the same equilibrium outcome: community planners will always set local income tax rates at or close to zero. In fact, the intuitive argument as well as the simulation results indicate that setting local income tax rates to zero is a dominant strategy for community planners. When faced with popular sentiment against the property tax, community planners can collude and introduce local income taxes simultaneously to prevent adverse general equilibrium migration and price changes. Since zero income tax rates are dominant strategies, however, such an agreement is only enforceable if an outsider such as the state government steps in. State grants funded through a state income tax can play such an enforcement role.
\end{abstract}

Thomas J. Nechyba

Department of Economics

Stanford University

Stanford, CA 94305-6072

and NBER 


\section{Introduction}

The use of property taxes to finance local public goods (LPGs) in general and education in particular is so predominant that it can hardly be dismissed as a mere historic accident. In $1988-89$, for example, over $97 \%$ of local tax revenues raised by politically independent US school districts were raised through property taxes (Strauss (1993)). At the same time, however, the public disdain for this method of taxation and its alleged inequities is widespread and growing. Tax revolts initiated in California in the 1970's have led to caps on property tax rates in many states, while legislators in Michigan, without having agreed to an alternative revenue raising mechanism, recently abolished the use of property taxation for funding education. Some investigations of these tax revolts indicate that they represent a desire on the part of voters to lower property tax rates, not to restrict levels of services (Courant, Gramlich and Rubinfeld (1980)). While voters are thus apparently demanding a change (rather than a reduction) in the funding of public goods, local politicians seem to leave it to higher levels of governments to respond to these demands (through tax limitations and grants in aid). The result of these tax limitation measures in the US seems to have been a shift from financing LPGs solely through property taxation to using state income taxes as well (De Tray and Fernandez (1986)). ${ }^{1}$

Therefore, while it is often suggested that their relative proximity to voters makes local governments more responsive to local political pressures, this does not seem to be the case here. Despite widespread dissatisfaction with the property tax and its perceived redistributive inequities, local governments continue to use it as their primary tax instrument while voters look to state governments to restrain or abolish it. We therefore must explain not only (i) why the property tax (rather than something like an income tax) has become the primary local tax strategy, ${ }^{2}$ but also (ii)

1 In addition, the presence of the well-known flypaper effect (see Gramlich (1977)) provides some tentative evidence that this change in tax policy is consistent with local voting. The flypaper effect implies that state governments can raise income taxes in a community, hand the revenues to the local government, and effect significantly higher local spending. In Nechyba (1994b) we demonstrate in the context of our model that often a majority of residents is better off under such a scheme.

2 A primary argument in favor of the local property tax has been the relative ease with which buildings can be observed by local authorities. With a well established system of state and national income taxes, however, incomes are now perhaps even more easily observed by local authorities than property values. It therefore seems eminently feasible for local communities to simply "piggyback" on the state or national income tax, a process which could be relatively costless and politically acceptable in light of the high costs of administering local property tax systems with perpetual reassessments that produce an endless flow of allegations of unfairness. 
why, when confronted with political pressures against the property tax, local governments leave the response to states and stubbornly refuse to change their local tax apparatus.

Previous work that analyzes the effects of different local tax systems includes Pogodzinski and Sjoquist (1993) and Krelove (1993). Of these, the latter explicitly endogenizes the choice of local taxes while the former simply demonstrates that income and property taxes have different equilibrium outcomes. In particular, Pogodzinski and Sjoquist analyze examples of a model which is, in many ways, similar to the model in this paper. Their contribution consists mainly of demonstrating that local property and income tax regimes have different effects in a general equilibrium (GE) world unless agents are identical in both endowments and preferences. We seek to build on this contribution here by analyzing, within a more general framework, how the constrained equilibrium effects of different local taxes determine the choice of tax systems when this choice is endogenized.

Unlike Pogodzinski and Sjoquist, Krelove (1993) seeks to directly endogenize local tax systems, but both his focus and approach differ substantially from ours. He characterizes equilibria in a model of competitive communities that seek to maximize net land rents and that are constrained to using a property tax (on housing), a tax on immobile land or a tax on mobile capital (used to produce housing). All agents are identical in their endowments and preferences, are fully mobile and consume both a private good and a congestible LPG. Krelove's main focus (as well his most important contribution) is to demonstrate that, contrary to conventional wisdom, property rather than land taxes are second best when direct taxation is not an option, and that these taxes can be viewed as a type of congestion fee that arises in equilibrium. He does not explicitly compare property and income taxes, nor does he seek to shed light on the limitations placed on the structure of local tax systems by the migrations of heterogeneous individuals. To obtain purely analytical results, and to make full use of the utility taking assumption, he employs some severe restrictions that are nevertheless standard in much of the literature, including the assumption of identical preferences and endowments.

In contrast, we attempt to explain the persistence of local property taxes by drawing heavily on the idea of tax competition in the presence of consumer mobility as well as the role of heterogeneous agents endowed with income that is mobile and houses that are not. Previous discussions of tax competition have focused on the mobility of capital and have usually disregarded the mobility of consumers. The main conclusion has been that attempts by local governments to attract businesses 
result in inefficiently low levels of LPGs, but little has been said about the endogenous development of local tax systems in the face of such government behavior. 3 We depart from much of this literature by disregarding the commercial sector and focusing on an entirely different and previously ignored set of issues raised by tax competition. This analysis is particularly relevant for the many school districts that have little or no commercial base. It furthermore deviates from the previous literature by explicitly defining an empirically relevant political process, by allowing for multiple types of mobile consumers, and by modelling both property and income in a way that gives rise to important price, income and redistribution effects. Finally, we view communities as fixed in size, which implies that whenever an agent moves out of a community, another agent replaces him. ${ }^{4}$

Our political process is one in which voters determine the local property tax rate, and community planners set the level of local income taxes. This corresponds to the public choice process observed in many US school districts where property tax changes are subject to referenda while local income tax rates are set by local or state officials. While voters are myopic in both their location and voting behavior, community planners are fully aware of GE price and migration effects. Planners thus find themselves in a game of choosing the local tax mix given the actions of planners in other communities and the GE price, voting and migration consequences of their choices. We postulate six different

3 Zodrow and Mieszkowski (1986) construct a model in which jurisdictions compete for capital investment by holding down a source based tax on capital to finance LPGs. A similar argument is put forward by Wilson (1986). Gordon (1986), however, demonstrates that, when other tax instruments are available, a local government of the Zodrow/Mieszkowski type would simply make use of residence based capital taxation in lieu of the source based variant, a finding contradicted empirically by the widespread use of property taxes. Bucovetsky and Wilson (1991) find that when both residence and source based taxation are available, local governments provide efficient levels of LPGs. They conclude, therefore, that the absence of residence based taxation in Zodrow and Mieszkowski accounts for the inefficiency. Agents in their model, however, are immobile. Most recently, Wilson (1994) incorporates mobility of both capital and labor and concludes that, in the absence of head taxes, local governments may underprovide LPGs, but that this underprovision is more severe under labor taxes than property taxes.

Wildasin, in a series of papers on tax competition, uses a Nash equilibrium approach with immobile agents, and in Wildasin (1991) casts the problem in a "duopolity" (two government) framework . By viewing tax competition as an externality, he constructs a corrective subsidy (Wildasin (1989)), while in Wildasin (1988) he demonstrates how Nash equilibrium outcomes may differ depending on whether tax rates or expenditure levels are used as the strategic variables. Bucovetsky (1991) analyses a two jurisdiction world using the concept of Nash equilibrium and a tax on a mobile base. Due to the tax competition between the jurisdictions, a merger is shown to improve efficiency. Further models (Wilson (1987), Wildasin (1993)) have added trade and specialization to the tax competition framework. More recently, Coates (1993) uses a repeated game setting to show that, in the presence of head taxes, negative tax rates intended to attract capital emerge.

4 While this may actually understate our result, we think it is a convenient short run approximation that allows for a closer focus on migration. In addition, it is our view that more and more suburbs are limited in the number of empty plots available for building, which implies that they are more and more fixed in size. 
objective functions for community planners and attempt to ascertain the mix of equilibrium local income and property taxes arising from these functions. It is our conclusion that regardless of which objective function is employed, it is a dominant strategy for planners to set the local income tax close to zero. This implies that property taxation arises as the sole local tax strategy in every community under every one of the six postulated objective functions for planners. Furthermore, if we hypothesize exogenous local dissatisfaction with the property tax, we find that local planners are caught in a classic prisoner's dilemma. Local (myopic) political pressures may demand less reliance on the very tax whose exclusive use is the dominant strategy for non-myopic planners. The uniform introduction of an income tax across all jurisdictions would eliminate the intercommunity tax competition responsible for the behavior of local planners while making the reduction of property tax rates possible. Therefore, an agreement between communities to jointly introduce local income taxes would allow for the alleviation of local myopic political pressures while preventing the competitive pressures associated with unilateral introductions of income taxes. Such an agreement, however, would not be self-enforcing as each local planner has an incentive to deviate. One possible enforcer to the agreement is the state government that can simply dictate the terms of the agreement by introducing a uniform state income tax and returning tax revenues to the respective jurisdictions. The model introduced here may therefore explain both (i) the widespread use and persistence of the local property tax as well as (ii) the equally widespread existence of state intervention that leads to increased use of income taxes to fund LPGs. 5

The paper is motivated by an intuitive example in Section II that lacks some of the analytic rigor of a complete theoretical analysis elsewhere (Nechyba (1994b)). We then test the intuitions gained from this example in simulations that allow for a more general environment. In particular, Section III specifies a formal model as well as its computable general equilibrium (CGE) counterpart parameterized to New Jersey micro tax data. ${ }^{6}$ Section IV briefly discusses the computation of equilibria, and Section V calculates constrained equilibria in which the planners' choices of local tax systems are held fixed. The various sets of equilibria then enable us to infer, given an objective function, the approximate mix of local property and income taxes chosen by a non-myopic planner. Section VI ends with some concluding comments.

5 This corresponds closely with, for example, recent developments in Michigan.

6 To our knowledge, this is the first CGE model in the public finance literature that is parameterized to real data. 


\section{Migration Effects from Local Tax Reform: Some Intuition?}

Suppose an economy was composed of many communities whose borders are exogenously given, and that two of these communities are arbitrarily labeled Community 1 and 2. Suppose further that each agent in this economy is endowed with one house in some community as well as some private good called income. Agents are freely mobile and able to buy and sell houses at market prices. In equilibrium, however, each agent owns one and only one house. Furthermore, he consumes a local public good (LPG) financed entirely through flat local taxes on income and property. A community planner in each community chooses the mix of income and property in the local tax base and is constrained to keep his government budget balanced. ${ }^{8}$ Finally, houses cannot be altered and no new houses can be built; i.e. the only way an agent can change his housing consumption is by moving. Houses are labeled A, B, C..., their equilibrium owners a, b, c..., their equilibrium values (prices) $P_{A}, P_{B}, P_{C} \ldots$ and the owners' incomes (private good endowments) $I_{a}, I_{b}, I_{c} \ldots$ respectively.

Suppose that the planner in community 1 enacts a revenue neutral tax reform that replaces part of the property tax with an increase in the income tax (while keeping LPG levels constant). We will assume for now that prices are sticky in the short run and investigate the patterns of migrations resulting from this reform. The reform will affect agents in community 1 in different ways depending on the ratio of their income to property holdings relative to the community average $\mu$. In particular, a's tax bill rises as a result of the tax reform if and only if $\frac{I_{a}}{P_{A}}>\mu$, whereas it falls if and only if $\frac{I_{a}}{P_{A}}<\mu$. Suppose that, as a result of the tax reform, agent $\mathrm{c}$ moves from outside community 1 into house $\mathrm{A}$. Given the nature of the housing market, agent a must then either purchase a different house in community 1 (Case 2 in Figure 1 ) or leave community 1 entirely (Case 1).

Suppose first that agent a leaves the community and is replaces by agent $c$ from community 2 (Case 1). Since nothing except for the financing of the LPG has changed, agent a must have been made worse off by the community's move toward an increased use of the income tax which implies $\frac{I_{a}}{P_{A}} \geq \mu$. Similarly, given that he previously preferred $\mathrm{C}$ to $\mathrm{A}$ and now prefers $\mathrm{A}$ to $\mathrm{C}$, agent $\mathrm{c}$ must now be

7 Theorems 4.1 and 4.2 in Nechyba (1994b) formalize the intuition presented in this section. These theorems are left out here in order to avoid the development of additional cumbersome notation that adds little to the argument.

8 For now we therefore abstract away from the more general political institutions in Section III. 


\section{FIGURE 1}

\section{Migration Effects from Raising Income in Local Income Tax in Community 1}

CASE

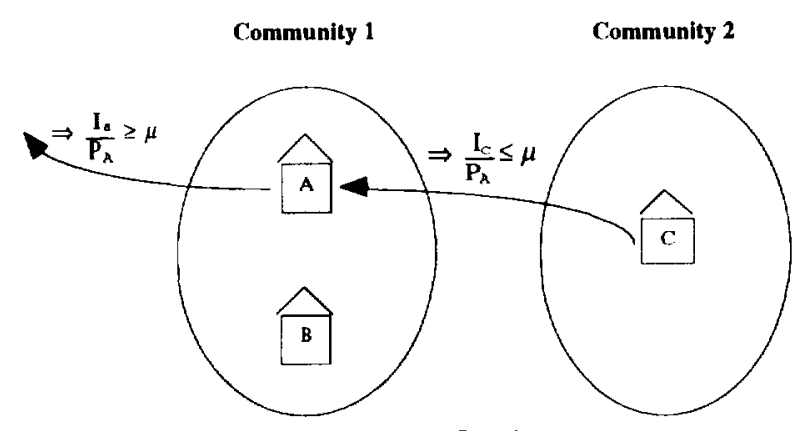

$\Rightarrow \mathbf{I}_{\mathbf{c}} \leq \mathbf{I}_{\mathrm{a}}$
CASE 2

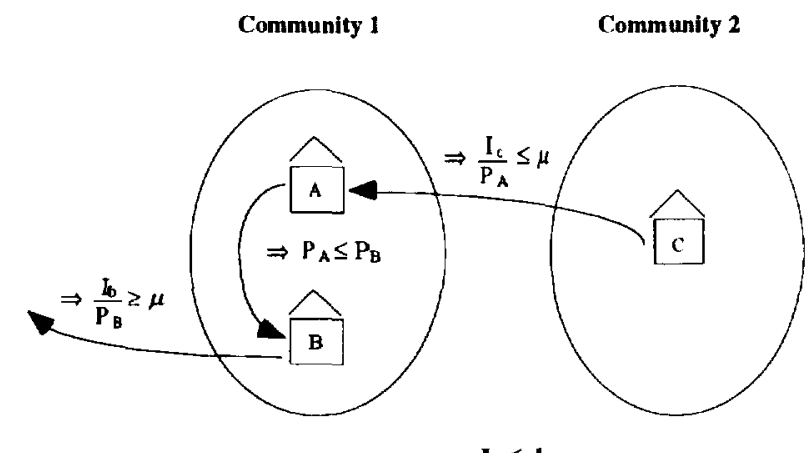

$\Rightarrow \mathbf{I}_{\mathrm{c}} \leq \mathrm{I}_{\mathrm{b}}$

better off in house $A$ than he would have been prior to the tax reform, i.e. $\frac{I_{c}}{P_{A}} \leq \mu$. This immediately implies that in Case 1 , the emigrant has more income than the immigrant $\left(I_{a} \geq I_{c}\right){ }^{9}$

Now suppose $b$ leaves the community and is replaced by a who in turn is replaced by c (Case 2 ). By the same reasoning as before, it is immediate that $\frac{I_{c}}{P_{A}} \leq \mu \leq \frac{I_{b}}{P_{B}}$ which is sufficient to reach the same conclusion as in case 1 (i.e. that the emigrant has more income than the immigrant $\left(I_{b} \geq I_{c}\right)$ ) if $P_{A} \leq P_{B}$. The fact that a moves within community 1 from $A$ to $B$ indicates strongly that this is indeed the case. More precisely, there are two possible cases: (i) $\frac{I_{a}}{P_{A}} \leq \mu$ (a was made better off in house $A$ ), and (ii) $\frac{I_{a}}{P_{A}}>\mu$ (a was made worse off in house A). Suppose first that (i) holds. Then agent a has become better off while housing has become cheaper due to the property tax decline. Assuming housing is a normal good, if agent a moves within community 1 , he will therefore choose to purchase more housing which means $P_{A} \leq P_{B}$. Suppose, on the other hand, that (ii) holds. If we assume that there are many communities in the economy, some of which provide opportunities yielding as much (or almost as much) utility for agent a as he enjoyed in house A before the tax reform, then he would move within community 1 only if he can maintain pre-reform utility levels by staying within the community. Since he initially preferred A to B, B must have become more desirable with the tax

9 If we assumed moving costs of $\varepsilon$ arbitrarily close to 0 , then all inequalities would automatically become strict. 
reform. This can only be true if $\frac{I_{a}}{P_{B}}<\mu\left(<\frac{I_{a}}{P_{A}}\right)$ which implies $P_{A}<P_{B}$. Some plausible assumptions then lead us to conclude $I_{b} \geq I_{c}$. We could further suppose that agent $b$ moved to some house $D$ in community 1 and that $\mathrm{d}$ leaves the community, but the same reasoning as in Case 2 continues to hold.

Therefore, under the restrictions outlined above, a simple argument suggests that one community's increased reliance on local income taxes would cause community income to fall. It should be noted, however, that this occurs not because high income types leave the community to be replaced with low income types. In fact, there is nothing in the above argument that suggests agents in any particular income category will emigrate. Rather, emigrants will be those whose ratio of income to property is relatively high, which will include both high and low income types. Regardless of the emigrant's income, however, even if he is the lowest income member of community 1 , he will be replaced by someone with less income.

Instead of analyzing a reform proposal aimed at increasing the role of local income taxes, we could investigate the migration effects of a revenue neutral tax reform that lowers income taxes in favor of increased property taxation. The same reasoning as above, however, leads to the exact opposite conclusion: community l's move toward increased reliance on the property tax would cause every emigrant to have less income than the immigrant replacing him. Therefore, a fairly intuitive argument against local income taxation and in favor of local property taxes flows out of this stylized example. ${ }^{10}$ A community's move toward local income taxation seems to be a move toward a tax base that is doomed to shrink as migration takes place. This implies a combination of future cuts in the provision of local public services and increases in local tax rates, which in turn will lead to further migration. The opposite holds for unilateral tax policy shifts away from income taxation and toward property taxes.

The crucial assumptions we have made are (i) housing is a normal good in fixed supply and available in discrete units, (ii) agents have reasonably attractive opportunities outside their community, (iii) reform proposals are revenue neutral, and (iv) prices are sticky. The first of these assumptions implies that moving is the only way for agents to change their housing consumption which corresponds somewhat to real world observations ${ }^{11}$ while allowing a close focus on migration

10 We have not yet specified the community planner's objective function and, for now, implicitly assume it to be increasing in community income.

11 High migration rates, especially intra-jurisdictional migration, indicate that moving is indeed a major avenue taken by individuals to changing their housing levels. This large degree of mobility is documented in the literature on 
effects. Furthermore, housing is clearly not an inferior good. We therefore regard assumption (i) as relatively minor, especially in the context of a short run model of an urban economy in which there is little or no empty land for construction. Similarly, assumption (ii) can reasonably be expected to hold in most urban areas where local communities (school districts) are plentiful ${ }^{12}$ and interjurisdictional migration entails few more costs than intrajurisdictional moves. Assumptions (iii) and (iv), however, are more worrisome. In particular, there is typically considerable local voter input in determining local public good levels which implies local service levels will change with a change in the local tax system. In many communities in the US, for example, local property tax rates (and therefore the levels of LPGs) are ratified in public referenda while local income tax rates are set either by the state or local government. (This is the public choice process we seek to model in the next section.) Similarly, prices cannot be expected to be sticky for long as consumer demands change in the face of new local tax rules. Unfortunately, no a priori conclusion can be made about the eventual direction of property values. On the one hand, a move away from taxation of house values would tend to raise property values, while, on the other hand, the shrinking local tax base would force an increase in tax rates and a reduction of public services, both of which will depress property values and cause further migration. Similar forces are at work when a community shifts from income to property taxes.

We therefore proceed to subject the intuitions developed here to CGE simulations which relax assumptions (ii) through (iv). These simulations allow for the endogenous development of community populations (migrations), prices (property values) and LPG levels (as determined through majority rule voting). In the process we will assume different objective functions for a community planner that chooses the structure of the local tax system and attempt to determine his optimal choices given those objective functions. This is the first calibrated CGE model we are aware of in the literature, and the first to employ a fully closed model with land (house) endowments. The intuition in favor of the property tax survives and is strengthened in this general equilibrium environment.

housing and tenure choice (see, for example, Hanushek and Quigley (1978) and Ioannides (1987)). Approximately 20 percent of metropolitan residents move each year, two thirds of which move within their metropolitan area.

12 Within ten miles of Camden City, New Jersey, for example, there are close to thirty different school districts. (Several of these districts are used to parameterize the computable general equilibrium model presented in the next section.) 
TABLE 1

Summary of Computable General Equilibrium Model Including Parameter Values

\begin{tabular}{|c|c|c|}
\hline Community Structure & $C=\left\{C_{m h} \subset N \mid(m, h) \in M \times H\right\}$ & $\mathrm{N}=[0,1] ; \mathrm{M}=\{1,2,3\} ; \mathrm{H}=\{1,2,3\} ;$ and $\mu\left(\mathrm{C}_{\mathrm{ih}}\right)=\frac{1}{9} \forall(\mathrm{m}, \mathrm{h})$ \\
\hline Endowment Types & $E=\left\{E_{m h i} I(m, h, i) \in M \times H \times I\right\}$ & $\begin{array}{l}\mathrm{I}=\{1,2,3,4,5\} ; \mu\left(\mathrm{E}_{\mathrm{mhi}}\right)=\frac{1}{45} \forall(\mathrm{m}, \mathrm{h}, \mathrm{i}) ; \text { and } \\
\left.\left(z\left(\mathrm{e}_{\mathrm{mh} 1}\right), \ldots, z\left(\mathrm{e}_{\mathrm{mhS}}\right)\right)=(2,3.5,5,6.5,8) \forall \mathrm{fm}, \mathrm{h}\right)\end{array}$ \\
\hline Preferences & $\mathrm{U}=\left\{u^{\mathrm{n}}: \mathrm{M} \times \mathrm{H} \times R_{+}^{\overline{\mathrm{m}}+2} \rightarrow R_{+} \mid \mathrm{n} \in \mathrm{N}\right\}$ & $\begin{array}{l}u^{\mathrm{n}}(\mathrm{m}, \mathrm{h}, \mathrm{x}, \mathrm{z})=\mathrm{k}_{\mathrm{mh}} \mathrm{x}_{0}^{\alpha} \times \mathrm{x}_{\mathrm{m}}^{\mathrm{B}} \mathrm{z}^{\gamma} \forall \mathrm{n} \in \mathrm{N} \text { where } \\
\quad(\alpha, \beta, \gamma)=(0.13,0.06,0.64) \text {, and } \\
\quad\left(\mathrm{k}_{11}, \ldots, \mathrm{k}_{13}, \mathrm{k}_{21}, \ldots, \mathrm{k}_{33}\right)= \\
(0.82,0.89,0.96,0.85,0.95,1.05,0.93,1.03,1.13)\end{array}$ \\
\hline Production of LPGs & $\mathrm{F}=\left\{f_{\mathrm{m}}: R_{+} \rightarrow R_{+} \mid \mathrm{m} \in \mathrm{M}\right\}$ & $f_{\mathrm{m}}(\mathrm{z})=\frac{\mathrm{z}}{\mu\left(\mathrm{C}_{\mathrm{m}}\right)} \Rightarrow \mathrm{x}_{0}\left(\mathrm{t}_{\mathrm{m}}, \overline{\mathrm{t}}_{\mathrm{m}}\right)=\frac{\mathrm{t}_{\mathrm{m}} p\left(\mathrm{C}_{\mathrm{m}}\right)+\overline{\mathrm{t}}_{\mathrm{m}} z\left(\mathrm{~J}_{\mathrm{m}}\right)}{\mu\left(\mathrm{C}_{\mathrm{m}}\right)}$ \\
\hline Production of SPG & $f_{0}: R_{+} \rightarrow R_{+}$ & $f_{0}(\mathrm{z})=\frac{\mathrm{z}}{\mu(\mathrm{N})} \Rightarrow \mathrm{x}_{0}\left(\mathrm{t}_{0}\right)=\frac{\mathrm{t}_{0} z(\mathrm{~N})}{\mu(\mathrm{N})}$ \\
\hline
\end{tabular}

\section{A Calibrated Computable General Equilibrium Model of Local Public Finance}

The computable general equilibrium (CGE) model developed here is calibrated to New Jersey data and is based on a theoretical model introduced in Nechyba (1994a) where the existence of an equilibrium is proved. The main elements of both the general model as well as its CGE derivative are summarized in Table 1. $\mathrm{N}$ represents both the set of agents and the set of houses in the model, where $\mathrm{n} \in \mathrm{N}$ is defined as that agent who is initially endowed with house $\mathrm{n} .{ }^{13}$ A fixed community structure

$$
\mathrm{C}=\left\{\mathrm{C}_{\mathrm{mh}} \subset \mathrm{N} \mid(\mathrm{m}, \mathrm{h}) \in \mathrm{M} \times \mathrm{H}, \underset{\mathrm{h} \in \mathrm{H}}{\cup} \mathrm{C}_{\mathrm{mh}} \neq \varnothing \forall \mathrm{m} \text { and } \mathrm{C}_{\mathrm{mh}} \cap \mathrm{C}_{\mathrm{m}^{\prime} \mathrm{h}^{\prime}}=\varnothing \forall(\mathrm{m}, \mathrm{h}) \neq\left(\mathrm{m}^{\prime}, \mathrm{h}^{\prime}\right)\right\}
$$

is imposed on this set of houses and partitions it into a set of house types $H=\{1, \ldots, \mathrm{h}, \ldots, \overline{\mathrm{h}}\}$ spread over a set of communities $M=\{1, \ldots, m, \ldots, \bar{m}\} . C_{m b}$, then, is both the set of houses of type $h$ in

13 More precisely, the set of houses and consumers is defined as part of a measure space $(N, \mathcal{N}, \mu)$ where $\mu$ is taken to be the Lebesgue measure. All subsets referred to are henceforth assumed to be measurable. 
community $m$ and the set of agents initially endowed with such houses. The CGE model defines $\mathrm{N}=[0,1], \mathrm{H}=\{1,2,3\}$ and $\mathrm{M}=\{1,2,3\}$, which implies nine different house endowment types (3 house types in each of 3 communities), of which each is represented in the economy in equal numbers; i.e.

$$
\mu\left(\mathrm{C}_{\mathrm{mh}}\right)=\frac{1}{9} \text {. }
$$

In addition to his house, agent $\mathbf{n}$ is also endowed with a strictly positive amount of private good $z(\mathrm{n})$ called income. The set of income levels is finite which gives rise to a set of income classes $\mathrm{I}=$ $\{1, \ldots, \mathrm{i}, \ldots, \overline{\mathrm{i}})$. The house and income endowments then jointly define a set of endowment types

$$
\mathrm{E}=\left\{\mathrm{E}_{\mathrm{mhi}} \mid(\mathrm{m}, \mathrm{h}, \mathrm{i}) \in \mathrm{M} \times \mathrm{H} \times \mathrm{I}\right\}
$$

where $e_{m h i} \in E_{m h i}$ is an agent that falls into the income class $i$ and is endowed with a house of type $h$ in community $\mathrm{m}$. Our CGE model contains five of these income classes (with incomes of 2, 3.5, 5 , 6.5 and 8 roughly corresponding to household income levels scaled by $\$ 10,000$ ) which, combined with the three house types in each of three communities, generates 45 endowment types each of which is represented equally in the economy; i.e.

$$
\mu\left(\mathrm{E}_{\mathrm{mhi}}\right)=\frac{1}{45} \quad \forall(\mathrm{m}, \mathrm{h}, \mathrm{i}) \in \mathrm{M} \times \mathrm{H} \times \mathrm{I} .
$$

Finally, agents are endowed with a utility function $u^{\mathrm{n}}: \mathrm{M} \times \mathrm{H} \times R_{+}^{\overline{\mathrm{m}}+2} \rightarrow R_{+}$which takes as its arguments the community and house type the agent lives in, private good consumption $\mathrm{z} \in R_{+}$, and a vector of public goods $\left(\mathrm{x}_{0}, \mathrm{x}_{1}, \ldots, \mathrm{x}_{\overline{\mathrm{m}}}\right) \in R_{+}^{\overline{\mathrm{m}}+1}$ where $\mathrm{x}_{0}$ is the state (or national) public good (SPG) and $x_{m}$ (for $m \in M$ ) is the LPG produced in community $m$. In the CGE version, all agents have the same utility function which is defined so as to exclude the possibility of spillovers between jurisdictions:

$$
u^{\mathrm{n}}(\mathrm{m}, \mathrm{h}, \mathrm{x}, \mathrm{z})=\mathrm{k}_{\mathrm{mh}} \mathrm{x}_{0}^{\alpha} \mathrm{x}_{\mathrm{m}}^{\beta} \mathrm{z}^{\gamma} \quad \forall \mathrm{n} \in \mathrm{N} .14
$$

State and local public goods are produced according to production technologies defined by a set of production functions $\mathrm{F}=\left\{f_{\mathrm{i}}: R_{+} \rightarrow R_{+} \mid \mathrm{i} \in 0 \cup \mathrm{M}\right\}$ which convert private goods directly into public goods. In the CGE model, we define public good levels as per capita spending on the public good, i.e.

$$
f_{0}(\mathrm{z})=\frac{\mathrm{z}}{\mu(\mathrm{N})} \text { and } f_{\mathrm{m}}(\mathrm{z})=\frac{\mathrm{z}}{\mu\left(\mathrm{C}_{\mathrm{m}}\right)} \text { for } \mathrm{m} \in \mathrm{M}
$$

14 This utility function satisfies all conditions necessary for the existence of an equilibrium (Nechyba (1994a)). The parameters are set to be consistent with New Jersey micro tax data in a way described shortly. Preferences are assumed to be identical in this way not only for computational convenience but also because stratification results in Nechyba (1994a) imply that under these conditions, the equilibrium assignment of agents into house types is unique. 
The SPG is financed through a proportional income tax $t_{0}$, while LPGs are funded through local tax systems described by $\left\{\left(\mathrm{t}_{\mathrm{m}}, \overline{\mathrm{t}}_{\mathrm{m}}\right) \mid \mathrm{m} \in \mathbf{M}\right\}$ where $\mathrm{t}_{\mathrm{m}}$ and $\overline{\mathrm{t}}_{\mathrm{m}}$ are community $\mathrm{m}$ 's proportional property and income tax rates respectively. ${ }^{15}$ State income taxes and local property taxes are set through absolute majority rule voting by members of the relevant constituencies, while the local income tax rate is set exogenously by a community planner. As mentioned in the introduction, this corresponds to the public choice process in many communities (esp. school districts) in the US. Residents often vote on property tax changes but are rarely given the opportunity to change local income tax rates $\left(\bar{t}_{m}\right)$ which are set by either the local or state government. Residents are assumed to be myopic in the sense that they take community compositions, property values and $\bar{t}_{m}$ as given when they go to the polls which implies they do not calculate the election's general equilibrium price and migration effects nor the strategic impact of the election on the community planner. ${ }^{16}$ Since local budgets have to balance, the relationship between $t_{m}$ and $x_{m}$ is therefore one to one (given any $\bar{t}_{m}$ ) and is defined by:

$$
\mathrm{x}_{\mathrm{m}}\left(\mathrm{t}_{\mathrm{m}}, \overline{\mathrm{t}}_{\mathrm{m}}\right)=\frac{\mathrm{t}_{\mathrm{m}} p\left(\mathrm{C}_{\mathrm{m}}\right)+\overline{\mathrm{t}}_{\mathrm{m}} z\left(\mathrm{~J}_{\mathrm{m}}\right)}{\mu\left(\mathrm{C}_{\mathrm{m}}\right)} \forall \mathrm{m} \in \mathrm{M},
$$

where $p\left(\mathrm{C}_{\mathrm{m}}\right)=\sum_{\mathrm{h} \in \mathrm{H}}\left(\mu\left(\mathrm{C}_{\mathrm{mh}}\right) \tilde{p}\left(\mathrm{C}_{\mathrm{mh}}\right)\right)$ is the local property tax base (which varies with the endogenously determined house price function $\left.\tilde{p}: \mathrm{M} \times \mathrm{H} \rightarrow R_{+}\right)$and $z\left(\mathrm{~J}_{\mathrm{m}}\right)$ is the local income tax base (which varies with the equilibrium assignment

$$
\mathrm{J}=\left\{\mathrm{J}_{\mathrm{mb}} \subset \mathrm{N} \mid \mu\left(\mathrm{J}_{\mathrm{mb}}\right)=\mu\left(\mathrm{C}_{\mathrm{mb}}\right) \forall(\mathrm{m}, \mathrm{h}) \in \mathrm{M} \times \mathrm{H}\right\}
$$

of agents into communities and house types). ${ }^{17}$ This, combined with myopic voting and standard assumptions on preferences and technologies, is shown in Nechyba (1994a) to yield single peaked preferences over LPGs (or, equivalently, over property tax rates) which in turn implies the existence of local voting equilibria. ${ }^{18}$ Agents are assumed similarly myopic in their location decisions in that they

15 Note that both property and income taxation are nondistortionary in the sense that the total level of income and housing in unaffected.

I6 Myopic voting of this kind is standard in this literature (see, for example, Westhoff (1977), Dunz (1985), Epple, Filimon and Romer (1993)).

17 Both $\mathrm{J}$ and $\mathrm{C}$ are partitions of $\mathrm{N}$. The difference is that $\mathrm{C}$ assigns houses (and the initial distribution of agents) into house types and communities, while $\mathrm{J}$ gives the equilibrium assignment of agents into houses and communities.

18 Voters are assumed to vote separately on local and national issues. This produces a structurally induced equilibrium (Shepsle (1979)) in which voters hold fixed local public goods when voting in national elections and vice versa. The 
take other agents' locations, prices and public good levels as given when choosing their own location.

Given local income tax rates $\left(\overline{\mathrm{t}}_{1}, \ldots, \bar{t}_{\mathrm{m}}\right)$, a constrained equilibrium (whose existence is proved rigorously in Nechyba $\left.(1994 a)^{19}\right)$ is simply defined as a list $(p, t, x, J)$ of prices, tax rates, public good levels and assignments of agents to communities such that:

(i) prices clear the market; i.e. there is no excess demand or supply for any house;

(ii) all government budgets balance;

(iii) consumers cannot gain utility by moving; and

(iv) local property and state income tax rates are determined through majority rule voting.

An unconstrained equilibrium is a constrained equilibrium that endogenizes the local income tax rates $\left(\overline{\mathrm{t}}_{1}, \ldots, \bar{t}_{\bar{m}}\right)$ to maximize each community planner's objective. While voters are assumed to be myopic, community planners are not. More precisely, community planners are assumed to understand the general equilibrium consequences of introducing various levels of local income tax rates $\bar{t}_{\mathrm{m}}$. They are therefore able to generate a set of local income and tax rates that is constrained by general equilibrium prices, voting and migration behavior as well as the actions of planners elsewhere. In light of this, we investigate the choice of $\bar{t}_{\mathrm{m}}$ under six objective functions for the community planner:

(1) To maximize community income;

(2) To maximize community property values;

(3) To maximize local wealth;

(4) To maximize local utility levels;

(5) To maximize the size of the local public sector; and

(6) To satisfy the current median voter.

While our motivating example in Section II suggests an optimal $\bar{t}_{\mathrm{m}}$ of zero for the first of these objective functions, it can only lead to conjectures about the other five. The remarkable conclusion suggested by the general equilibrium simulations is that, for the same reasons, this optimal $\bar{t}_{\mathrm{m}}$ is the same regardless of which objective function the community planner employs.

same conditions that guarantee a local voting equilibrium then also guarantee a national voting equilibrium.

19 The existence of a constrained equilibrium is proved in the presence of no local income taxes; i.e. $i_{\mathrm{m}}=0$ for all $m \in M$. The same proof, however, is applicable for any $\left(\bar{t}_{1}, \ldots, \bar{t}_{\bar{m}}\right)$. 


\section{Calibration of the Model}

The main data set used for the calibration of the CGE model is taken from information on ninety percent of 1987 income tax payers and homestead rebate recipients in six school districts of Camden County, New Jersey. In particular, income information from New Jersey tax forms is matched with property information from homestead rebate claims for each individual to form a unique data set containing both income and property information on an individual basis. Thus, each individual's income (by category), exemptions, property value, and community (school district) is known. ${ }^{20}$

A second data set is used to impute federal income taxes for each observation in the New Jersey tax sample. It contains the complete federal income tax forms for 3000 New Jersey residents for the year 1987. This set is divided into two dimensional cells based on the number of claimed exemptions and 24 brackets of the New Jersey definition of gross income. Then, the median federal tax bill within each cell is matched to agents in the New Jersey tax sample by both the income brackets and the number of exemptions. We thus impute federal tax liability to each individual in the New Jersey sample. ${ }^{21}$

The LPG of most interest in residential location choices is primary and secondary public education. In New Jersey, school districts are independent political units that use property taxation as a local means of financing school spending. Furthermore, school districts are coterminous with local municipalities, and each municipality is fully contained in a school district. ${ }^{22}$ In this study, we select a section of Camden County which includes poor, middle income and high income districts in close proximity to one another. ${ }^{23}$ From these districts, we pick non-elderly (below 65) individuals with more than one exemption whose income lies between $\$ 10,000$ and $\$ 250,000$ per year. For each individual, we calculate from the value of his assessed property (adjusted by the local assessment to true value ratio ${ }^{24}$ ) a yearly "mortgage payment" assuming a fixed rate mortgage with $7 \%$ interest. Thus, we calculate housing consumption levels $\widetilde{\mathrm{h}}$ for each individual $\mathrm{n}$ and assume it enters as an

20 This data set was generously provided by William T. Bogart. For a detailed description, see Bogart (1990).

21 The federal tax data was provided by R. Strauss. For a detailed description, see Internal Revenue Service (1987).

22 In some cases school districts are composed of more than one municipality, although that is not true for any of the school districts in this study.

23 The districts are: Camden City, Cherry Hill, Collingswood, Haddon, Haddon Heights and Pennsauken. For a more detailed description of this data, see Nechyba and Strauss (1994).

24 Assessment ratios are calculated yearly based on homes that sold that year (New Jersey Associates (1988)). 
TABLE 2

Summary Statistics for Utility Function Parameters

\begin{tabular}{cccc}
\hline & Mean & Median & Std. Deviation \\
$\delta$ & 0.17 & 0.16 & 0.118 \\
$\alpha$ & 0.13 & 0.13 & 0.055 \\
$\beta$ & 0.06 & 0.06 & 0.027 \\
$\gamma$ & 0.64 & 0.65 & 0.128 \\
\hline
\end{tabular}

argument in his Cobb-Douglas utility function:

$$
\begin{aligned}
& u^{\mathrm{n}}(\mathrm{m}, \widetilde{\mathrm{h}}, \mathrm{x}, \mathrm{z})=\widetilde{\mathrm{h}}^{\delta(\mathrm{n})} \mathrm{x}_{0}^{\alpha(\mathrm{n})} \mathrm{x}_{\mathrm{m}}^{\beta(\mathrm{n})} \mathrm{z}^{\gamma(\mathrm{n})} \text {, where } \\
& \alpha(n)+\beta(n)+\gamma(n)+\delta(n)=1 \text { and } \alpha(n), \beta(n), \gamma(n), \delta(n)>0 \text {. }
\end{aligned}
$$

Note that since housing here is a continuous variable, $\tilde{h}^{\delta(n)}$ plays a role similar to that of $k_{m h}$ in (5).

When treated as an ordinary maximization problem where agent $n$ chooses levels of $\widetilde{h}, x_{m}$ and $z$ subject to some budget constraint, demand equations for each good are simply a function of the agent's income $z(n)$ and that good's price and can be readily solved for $\beta(n), \delta(n)$ and $\gamma(n)$ :

$$
\begin{array}{rll}
\widetilde{\mathrm{h}}^{*}(\mathrm{n})=\frac{\delta(\mathrm{n}) z(\mathrm{n})}{\mathrm{p}_{\mathrm{h}}^{\tilde{}}} & \Rightarrow & \delta(\mathrm{n})=\frac{\widetilde{\mathrm{h}}^{*}(\mathrm{n}) \mathrm{p}_{\mathrm{h}}^{\sim}}{z(\mathrm{n})} \\
\mathrm{x}_{\mathrm{m}}^{*}(\mathrm{n})=\frac{\beta(\mathrm{n}) z(\mathrm{n})}{\mathrm{p}_{\mathrm{x}_{\mathrm{m}}}} & \Rightarrow & \beta(\mathrm{n})=\frac{\mathrm{x}_{\mathrm{m}}^{*}(\mathrm{n}) \mathrm{p}_{\mathrm{x}_{\mathrm{m}}}}{z(\mathrm{n})} \\
\mathrm{z}^{*}(\mathrm{n})=\frac{\gamma(\mathrm{n}) z(\mathrm{n})}{\mathrm{p}_{\mathrm{z}}} & \Rightarrow & \gamma(\mathrm{n})=\frac{\mathrm{z}^{*}(\mathrm{n}) \mathrm{p}_{\mathrm{z}}}{z(\mathrm{n})}
\end{array}
$$

Note that the data provide for each agent $\mathrm{n}$ the levels of $z(\mathrm{n})$ (his before tax income), $\widetilde{\mathrm{h}}^{*}(\mathrm{n})$ (the calculated mortgage payment), $x_{m}^{*}(n)$ (per pupil school spending in the relevant district $\mathrm{m}^{25}$ ) and $\mathrm{z}^{*}(\mathrm{n})$ (consumption=total income minus federal, state and local tax payments and minus the calculated mortgage payment). Furthermore, since $\widetilde{h}$ and $z$ are expressed in dollar units, $p_{x_{m}}=p_{z}=1$. Finally, the tax price for $x_{m}$ differs for each individual and is given by

$$
\mathrm{p}_{\mathrm{x}_{\mathrm{mI}}}=\frac{\text { local tax payment by individual } \mathrm{n}}{\text { per pupil spending on education in n's district }} .
$$

25 These are published in State of New Jersey (1988). For our purposes, we defined $x_{m}$ as a three year average of per pupil school spending for school district $m$ (for the years $1985,86,87$ ). Although agents do not literally choose their most preferred level of $x_{m}$, they choose their place of residence with the level of $x_{m}$ in mind. 
We thus observe all the variables in equations (10), (11) and (12) needed to solve for the parameters $\delta(n), \beta(n)$ and $\gamma(n)$ for each $n$, and $\alpha(n)$ is just the residual $1-\delta(n)-\beta(n)-\gamma(n)$. These parameters are calculated for each agent in the sample, and their mean, median and standard deviation are reported in Table 2. The mean values for $\alpha, \beta$ and $\gamma$ are used directly as our parameter estimates in the utility function (5), while the mean of $\delta$ is used to estimate the nine housing parameters $\left(\mathrm{k}_{\mathrm{mh}}\right)$ in (5). In particular, a low, middle and high income school district in New Jersey is chosen, the range of property values in each district divided into quartiles and the property value at the 25 th $\left(\tilde{\mathrm{h}}_{25}\right)$, the 50 th $\left(\widetilde{\mathrm{h}}_{50}\right)$ and the 75 th percentile $\left(\tilde{\mathrm{h}}_{75}\right)$ taken as three representative values of $\tilde{\mathrm{h}}$ for that district. These nine values (divided by 10,000 ) are then used to set the housing parameter values such that $\mathrm{k}_{\mathrm{mh}}=\widetilde{\mathrm{h}}^{\delta}$. (The resulting estimates are reported in Table 1.)

\section{Calculating a Constrained Equilibrium}

Due to the computational complexities of the problem, we calculate constrained equilibria (i.e. equilibria in which the community planner's choice of $\bar{t}_{m}$ is held fixed) and attempt to infer the optimal community planner's choice (given one of the six objective functions proposed in Section II) from observing the constrained general equilibrium outcomes.

The CGE program (illustrated in Figure 2) begins with the information contained in Table 1 as well as a vector of local income tax rates $\left(\overline{\mathrm{t}}_{1}, \ldots, \bar{t}_{\overline{\mathrm{m}}}\right)$, initial house prices and an initial level of the SPG. It iterates to an equilibrium by first finding local and state election outcomes, then determining equilibrium prices given those outcomes, then using those prices (and the new community compositions) to update election outcomes, and so forth. Note that during each major iteration, the program iterates to find equilibrium prices for given election outcomes. ${ }^{26}$

More precisely, the program uses the initial data to identify each community's median voter who takes prices, the SPG level and everyone's location as given. That voter's optimal choice determines the community's LPG level (and local property tax). Next, the median voter in the state election and the resulting SPG outcome (and state income tax rate) are identified. ${ }^{27}$ Given these election results,

26 The program is written in GAMS (General Algebraic Manipulation System).

27 Again, the median voter holds fixed all prices and everyone's location, as well as the majority rule LPG levels that were just selected. 
FIGURE 2

CGE Program to Calculate an Equilibrium

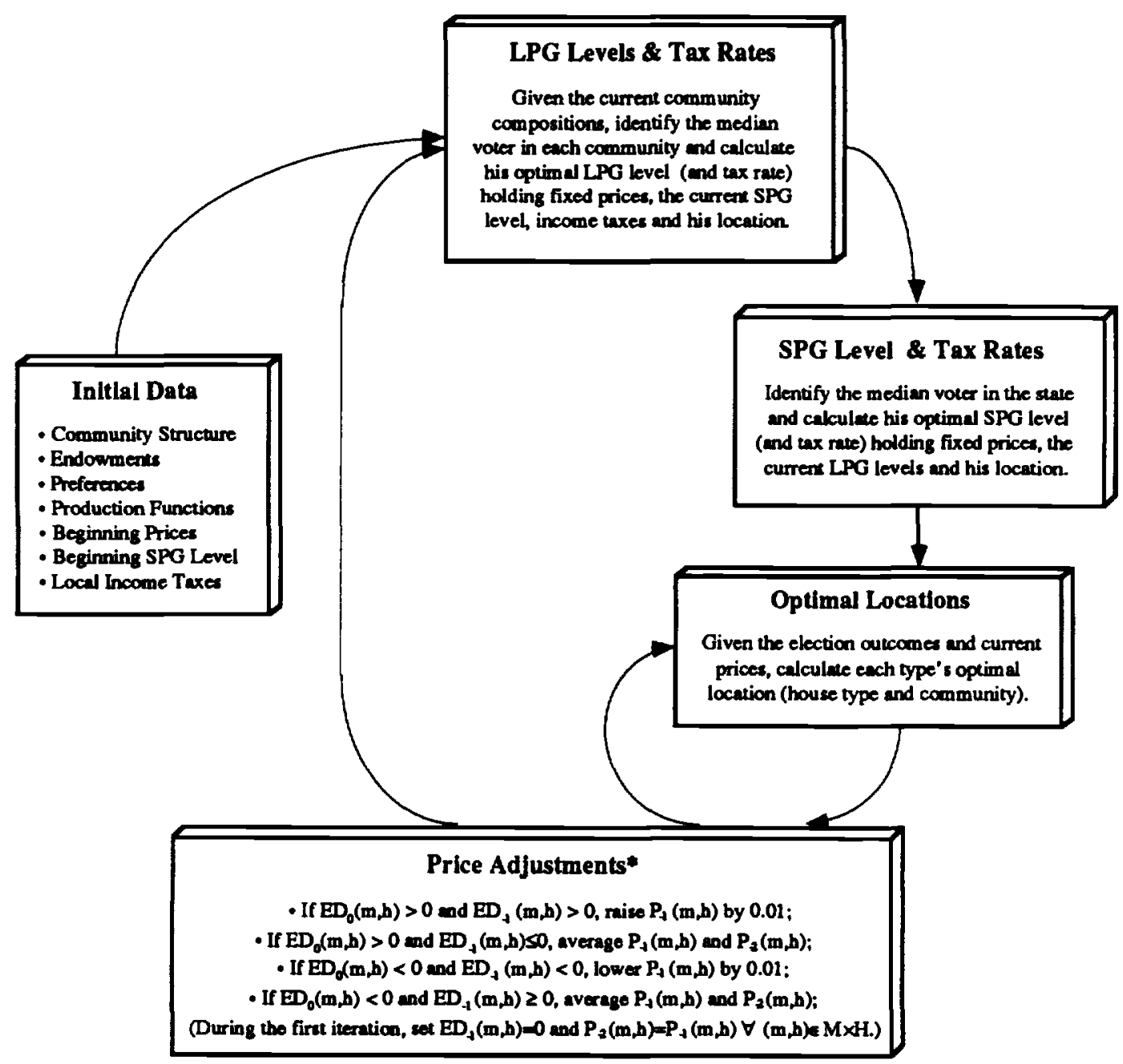

- $\mathrm{ED}_{0}(\mathrm{~m}, \mathrm{~h})$ and $\mathrm{ED}_{-1}(\mathrm{~m}, \mathrm{~h})$ stand for excess demand for $(m, h)$ during the current and previous iterations respectively. $P_{-1}(m, h)$ and $P_{-2}(m, h)$ stand for the prices of $(m, h)$ one and two iterations prior to the current iteration.

the program iterates to find equilibrium property values. In particular, during every iteration, each agent's optimal location at the current prices is determined and these prices are adjusted upward (by a fixed amount) if the house type in question was in excess demand during this and the past iteration and downward (by the same amount) if it was in excess supply during these iterations. If a particular house 
type alternated between being in excess demand and excess supply, the previous two prices are averaged. This process typically converges within twenty iterations. Once equilibrium prices have been found, i.e. once excess demands for all houses are zero, the program starts over with a new major iteration by identifying median voters in the new community populations. The process continues until the LPG and SPG levels, the local and state tax rates and the prices have converged. Throughout the process, the value of each agent's initial house endowment is used to determine that agent's budget. Values typically converge within fifteen major iterations and, due to the uniqueness of equilibrium assignments of agents into house types and communities, are only slightly sensitive to initial prices and SPG levels. ${ }^{28}$

\section{Results}

We begin by presenting two benchmark equilibria in Table 3 . The first of these is an equilibrium in which all communities use only property taxation; i.e. $\bar{t}_{m}=0$ for all $m \in M$. To contrast this equilibrium with its polar opposite, we also calculate an equilibrium in which planners set income taxes such that voters choose property tax rates of zero, i.e. an equilibrium in which only income taxes are used in every community. This local income tax equilibrium is reported as the second benchmark equilibrium in Table 3. Thus, the only difference in the two benchmark equilibria is that the first assumes exclusive use of the property tax by communities while the second assumes exclusive use of the income tax.

LPG and SPG levels can be interpreted as per capita spending by local and state governments. The LPG figures fall within the actual range of per pupil spending on education (roughly between $\$ 2500$ and $\$ 5000$ ) for Camden County, while the state public good level is close to the combined per capita state and national spending. The general figures in Table 3 confirm the speculation in Strauss (1993) that local tax structures have an impact on local equilibria by influencing the way agents segregate themselves. In both equilibria, agents separate into low, middle, and high income communities, but

28 In particular, as mentioned before, stratification results in Nechyba (1994a) state that, when preferences are identical and there are no spillovers (both of which are true in the CGE model), agents will separate into house types and communities in a way that makes this separation unique. Therefore, while the set of equilibria is not necessarily a singleton, it is unique in certain important dimensions (i.e. the assignment of agents into communities). Due to the limited number of house types, however, prices can vary within small intervals which implies that majority rule tax rates and public good levels can vary within small intervals. The program simply picks the first set of prices, public good levels and tax rates that satisfy the equilibrium conditions, but the assignment of agents is the same for any potential equilibrium. Therefore, there will occasionally be small deviations from persistent trends in the simulation results, but these are small enough not to detract from the overall conclusions. 
TABLE 3

Benchmark Equilibrium with Local Property Taxes*

\begin{tabular}{lccccccc}
\hline & Income & Wealth & Property & Consump. & Utility & Prop. Tax & LPG \\
\hline Community 1 & 3.3000 & 4.3900 & 0.6550 & 2.9462 & 1.5920 & 0.4247 & 0.2782 \\
Community 2 & 5.2000 & 6.3027 & 1.0250 & 4.0753 & 2.1449 & 0.3880 & 0.3977 \\
Community 3 & 6.5000 & 7.5573 & 1.5700 & 4.5568 & 2.5093 & 0.2706 & 0.4248 \\
\hline
\end{tabular}

House Values

\begin{tabular}{lcccc}
\hline & Type 1 & Type 2 & Type 3 & State Public Good Level \\
Community 1 & 0.4350 & 0.6301 & 0.9000 & 0.7737 \\
Community 2 & 0.5800 & 0.9799 & 1.5150 & State Income Tax Rate \\
Community 3 & 0.9900 & 1.5600 & 2.1600 & 0.1547 \\
\hline
\end{tabular}

Benchmark Equilibrium with Local Income Taxes

\begin{tabular}{lccccccc}
\hline & Income & Wealth & Property & Consump. & Utility & Inc. Tax & LPG \\
\hline Community 1 & 3.0000 & 4.0713 & 0.5023 & 2.9079 & 1.5781 & 0.0837 & 0.2664 \\
Community 2 & 4.9000 & 5.9434 & 0.8791 & 3.8948 & 2.0671 & 0.0742 & 0.3376 \\
Community 3 & 7.1000 & 8.0041 & 1.6510 & 4.7808 & 2.6022 & 0.0640 & 0.4650 \\
\hline
\end{tabular}

House Values

\begin{tabular}{lcccc}
\hline & Type 1 & Type 2 & Type 3 & National Public Good Level \\
Community 1 & 0.1044 & 0.4231 & 0.8010 & 0.7815 \\
Community 2 & 0.3012 & 0.8696 & 1.5837 & National Income Tax Rate \\
Community 3 & 0.9208 & 1.6510 & 2.4016 & 0.1565
\end{tabular}

*Note: All dollar values are scaled by $\$ 10000$. Property values are expressed as annual payments on a fixed rate mortgage at $7 \%$ interest. Property tax rates may appear high because they are tax rates on these annual payments, not on the full value of the property.

there is some overlap due to overlapping values of the $\mathrm{k}_{\mathrm{mh}}$ 's (see Table 1). Higher income communities tend to have higher LPG levels and lower property tax rates, and property values (the value of yearly housing services) tend to increase in community wealth. Although these results hold for both equilibria, they are significantly more pronounced in the case where local communities rely on 
local income taxes. The intuition for this is straightforward: Under income taxation, high income agents can expand their local tax base and thus reduce local tax prices by segregating themselves into separate communities. Under property taxation, on the other hand, the incomes of other members of the community have no impact on tax prices. High income agents are therefore more likely to segregate themselves under local income taxation which enables them to choose higher levels of LPGs at lower tax rates. The use of property rather then income taxes can thus be seen as causing greater integration based on incomes, less divergence of property values and more equal levels of LPGs.

We now investigate the general equilibrium effects of various local tax reforms starting at the first benchmark equilibrium. In particular, we trace the effects of unilateral introductions of local income taxes $\left(\bar{t}_{m}\right)$ by community 2's planner as prices adjust, agents migrate and voters vote on the local property tax. Then we reverse this experiment and begin with the second (income tax) benchmark equilibrium to analyze the effects of the unilateral phasing out of the income tax by community 2 's planners. ${ }^{29}$ It should be noted that each agent's wealth is now affected by price changes of his equilibrium house, not his initial house endowment (which he sold on his way to the benchmark equilibrium.) Post-reform equilibria are calculated in a way similar to the original calculations outlined in Figure 2 where the "Initial Data" are now given by the relevant benchmark equilibrium.

\section{A Community Planner's Unilateral Reform toward an Income Tax}

Table 4 reports the general equilibrium effects on average incomes, wealth, property values, consumption, utility levels, majority rule property tax rates and LPG levels of a decision by community 2's planner to introduce various levels of a local income tax rate $\bar{t}_{2}$.

Note that income in community 2 falls sharply as higher levels of $\bar{t}_{2}$ are introduced which contributes significantly to a decline in average wealth, ${ }^{30}$ consumption and utility levels. In fact, despite its inherent greater desirability (as expressed by the $\mathrm{k}_{\mathrm{ih}}$ 's), it changes positions with community 1 to become the lowest income community in the economy. Similarly, property values

29 We focus here on community 2 because it is most representative of real world communities in that it has both wealthier as well as poorer neighbors. Identical simulations were run for communities 1 and 3 with essentially the same qualitative results. (Simulation results for community 3 tended to be smaller in magnitude.)

30 An agent's wealth is the sum of his income (private good endowment), the benchmark equilibrium value of his original house endowment and the capital gain (or loss) incurred (through changes in the value of his benchmark equilibrium house) in going from one equilibrium to the next. 
TABLE 4

General Equilibrium Effects from a Community 2's Unilateral

Introduction of a Local Income Tax*

\begin{tabular}{|c|c|c|c|c|c|c|c|}
\hline & Income & Wealth & Property & Consump. & Utility & Prop. Tax & LPG \\
\hline \multicolumn{8}{|l|}{ Community 1} \\
\hline $0 \%$ Income Tax & 3.3000 & 4.3900 & 0.6550 & 2.9462 & 1.5920 & 0.4247 & 0.2782 \\
\hline $1 \%$ Income Tax & 3.4200 & 4.3718 & 0.6550 & 2.9138 & 1.5797 & 0.4093 & 0.2681 \\
\hline $2 \%$ Income Tax & 3.6000 & 4.3032 & 0.6659 & 2.8206 & 1.5427 & 0.3817 & 0.2542 \\
\hline 3\% Income Tax & 3.8000 & 4.6447 & 0.6538 & 3.1093 & 1.6495 & 0.4433 & 0.2898 \\
\hline $4 \%$ Income $\mathrm{Tax}$ & 3.5000 & 4.2983 & 0.6465 & 2.8452 & 1.5536 & 0.4040 & 0.2612 \\
\hline $5 \%$ Income Tax & 3.7500 & 4.4015 & 0.6428 & 2.8988 & 1.5760 & 0.4286 & 0.2755 \\
\hline $6 \%$ Income Tax & 3.9413 & 4.7378 & 0.6380 & 3.1939 & 1.6803 & 0.4484 & 0.2861 \\
\hline \multicolumn{8}{|l|}{ Community 2} \\
\hline $0 \%$ Income $\mathrm{Tax}$ & 5.2000 & 6.3027 & 1.0250 & 4.0753 & 2.1449 & 0.3880 & 0.3977 \\
\hline $1 \%$ Income Tax & 5.0800 & 6.3209 & 1.0250 & 4.1029 & 2.1576 & 0.3393 & 0.3985 \\
\hline $2 \%$ Income Tax & 4.2000 & 5.6953 & 1.0250 & 3.6638 & 1.9931 & 0.2597 & 0.3502 \\
\hline $3 \%$ Income Tax & 4.2000 & 5.5670 & 1.0153 & 3.5667 & 1.9524 & 0.2019 & 0.3310 \\
\hline $4 \%$ Income Tax & 4.2000 & 5.6342 & 1.0104 & 3.6428 & 1.9766 & 0.1568 & 0.3264 \\
\hline $5 \%$ Income Tax & 4.1000 & 5.5376 & 0.9995 & 3.5505 & 1.9521 & 0.1438 & 0.3488 \\
\hline $6 \%$ Income Tax & 3.9000 & 5.3117 & 0.9958 & 3.3783 & 1.8845 & 0.0907 & 0.3243 \\
\hline \multicolumn{8}{|l|}{ Community 3} \\
\hline 0\% Income Tax & 6.5000 & 7.5573 & 1.5700 & 4.5568 & 2.5093 & 0.2706 & 0.4248 \\
\hline $1 \%$ Income Tax & 6.5000 & 7.5573 & 1.5700 & 4.5469 & 2.5089 & 0.2700 & 0.4239 \\
\hline $2 \%$ Income Tax & 7.2000 & 8.2625 & 1.5700 & 5.0737 & 2.7080 & 0.3145 & 0.4937 \\
\hline $3 \%$ Income Tax & 7.0000 & 8.0309 & 1.5737 & 4.8659 & 2.6418 & 0.3185 & 0.5012 \\
\hline $4 \%$ Income Tax & 7.3000 & 8.3139 & 1.5895 & 5.0888 & 2.7142 & 0.3134 & 0.4981 \\
\hline $5 \%$ Income Tax & 7.1500 & 8.3000 & 1.5964 & 5.0898 & 2.7149 & 0.3126 & 0.4992 \\
\hline $6 \%$ Income $\mathrm{Tax}$ & 7.1587 & 8.1931 & 1.6089 & 4.9620 & 2.6754 & 0.3085 & 0.4964 \\
\hline
\end{tabular}

*Note: All dollar values are scaled by $\$ 10000$. Property values are expressed as annual payments on a fixed rate mortgage at $7 \%$ interest. Property tax rates may appear high because they are tax rates on these annual payments, not on the full value of the property.

decline despite a substantial drop in the local property tax rate from 0.39 to 0.09 . Finally, LPG levels fall significantly in community 2 . These effects can be contrasted to the trends in the other communities resulting from community 2's tax reform. These trends are either inconclusive or exactly opposite those in community 2 and are driven mainly by the substantial increases in community incomes resulting from migrations of agents in community 2 whose holdings of income to property are above that community's average. 
Whether the planner is a property value maximizer (as in, for example, Krelove (1993)), a budget maximizing bureaucrat or a maximizer of income, wealth or utility, the unconstrained equilibrium level of local income tax rates is thus always at or close to zero. Furthermore, while this is not borne out in Table 4, were the planner intent on satisfying the median voter in the benchmark equilibrium population, then the conclusion would be the same as well. In other words, when pre- and post-reform utility levels of each resident of community 2 in the benchmark equilibrium are calculated, significantly more than half of those members have higher pre-reform than post-reform utility for every level of $\overline{t_{2}}$ greater than 0.01 .

Thus, when property taxation is the uniform tax strategy employed by all community planners, it is also a best response for each particular planner. The simulation results therefore indicate that, regardless of the planners' objective functions, a constrained equilibrium in which local income tax rates are set to zero is in fact equivalent to an unconstrained equilibrium in which community planners can choose the mix of local property and income in local tax bases.

\section{A Community Planner's Unilateral Reform toward a Property Tax}

Next we investigate whether the same can be said for a constrained equilibrium in which all community planners rely predominantly on local income taxation. We now start with the latter equilibrium in Table 3 as the "Initial Data" for the CGE program (see Figure 2) and observe the general equilibrium changes as community 2's planner reduces local income taxes which causes voters to vote for positive property tax rates.

The results are exactly opposite those in Table 4 and are reported in Table 5. Community 2 experiences dramatic increases in income, wealth, property value, consumption, utility and LPG levels, while the flow of income into community 2 causes precisely the opposite to occur in the neighboring communities. While the increased use of income in its local tax base caused community 2 to become the lowest income community in Table 4, the increased reliance on property taxation makes it the highest income community in Table 5. Note further that despite increased property taxation, property values rise in community 2 and fall elsewhere. As before, this implies that wealth, income,

property value or utility maximizing planners as well as budget maximizing bureaucrats all agree on the need to set low income tax rates. Furthermore, as in the previous section, even a community planner 
TABLE 5

General Equilibrium Effects from a Community 2's Unilateral

Introduction of a Local Property Tax

\begin{tabular}{|c|c|c|c|c|c|c|c|}
\hline & Income & Wealth & Property & Consump. & Utility & Local Tax & LPG \\
\hline Community 1 & & & & & & Income Tax & \\
\hline Full Income Tax & 3.0000 & 4.0713 & 0.5023 & 2.9079 & 1.5781 & 0.0837 & 0.2664 \\
\hline 7\% Income Tax & 2.7000 & 3.8064 & 0.3978 & 2.7363 & 1.5120 & 0.0932 & 0.2514 \\
\hline $6 \%$ Income Tax & 2.7000 & 3.7926 & 0.3978 & 2.7212 & 1.5074 & 0.0931 & 0.2514 \\
\hline $5 \%$ Income Tax & 2.7000 & 3.8023 & 0.3990 & 2.7206 & 1.5104 & 0.0931 & 0.2514 \\
\hline $4 \%$ Income Tax & 2.6655 & 3.7750 & 0.4027 & 2.7067 & 1.5013 & 0.0931 & 0.2482 \\
\hline 3\% Income Tax & 2.6000 & 3.7542 & 0.4197 & 2.6841 & 1.4912 & 0.0931 & 0.2421 \\
\hline $2 \%$ Income Tax & 2.6000 & 3.7075 & 0.4258 & 2.6305 & 1.4755 & 0.0931 & 0.2421 \\
\hline $1 \%$ Income Tax & 2.6000 & 3.7215 & 0.4063 & 2.6657 & 1.4836 & 0.0924 & 0.2403 \\
\hline $0 \%$ Income Tax & 2.6000 & 3.7467 & 0.4088 & 2.6883 & 1.4924 & 0.0931 & 0.2421 \\
\hline Community 2 & & & & & & Property Tax & \\
\hline Full Income $T$. & 4.9000 & 5.9434 & 0.8791 & 3.8948 & 2.0671 & 0.0000 & 0.3376 \\
\hline $7 \%$ Income Tax & 5.4000 & 6.3840 & 0.9668 & 4.1339 & 2.1830 & 0.0660 & 0.4418 \\
\hline $6 \%$ Income Tax & 5.7333 & 6.4991 & 0.9827 & 4.1799 & 2.1992 & 0.0978 & 0.4401 \\
\hline $5 \%$ Income Tax & 6.0000 & 6.4270 & 0.9887 & 4.0792 & 2.1592 & 0.1196 & 0.4182 \\
\hline $4 \%$ Income Tax & 6.1345 & 6.5464 & 0.9814 & 4.1763 & 2.1938 & 0.1859 & 0.4278 \\
\hline $3 \%$ Income $\mathrm{Tax}$ & 6.2000 & 6.5908 & 0.9936 & 4.1887 & 2.2000 & 0.2503 & 0.4335 \\
\hline $2 \%$ Income Tax & 6.2000 & 6.6314 & 0.9881 & 4.2405 & 2.2156 & 0.3067 & 0.4247 \\
\hline $1 \%$ Income Tax & 6.3000 & 6.7062 & 0.9863 & 4.3114 & 2.2367 & 0.3632 & 0.4397 \\
\hline $0 \%$ Income $\mathrm{Tax}$ & 6.3000 & 6.6693 & 0.9778 & 4.2868 & 2.2273 & 0.4267 & 0.4172 \\
\hline Community 3 & & & & & & Income Tax & \\
\hline Full Income Tax & 7.1000 & 8.0041 & 1.6510 & 4.7808 & 2.6022 & 0.0640 & 0.4650 \\
\hline $7 \%$ Income Tax & 6.9000 & 7.7786 & 1.6043 & 4.6607 & 2.5512 & 0.0635 & 0.4384 \\
\hline $6 \%$ Income Tax & 6.5667 & 7.6565 & 1.5678 & 4.6408 & 2.5400 & 0.0641 & 0.4212 \\
\hline 5\% Income Tax & 6.3000 & 7.7141 & 1.5556 & 4.7218 & 2.5718 & 0.0713 & 0.4489 \\
\hline 4\% Income Tax & 6.2000 & 7.5964 & 1.5337 & 4.6434 & 2.5494 & 0.0723 & 0.4482 \\
\hline 3\% Income Tax & 6.2000 & 7.6105 & 1.5422 & 4.6463 & 2.5514 & 0.0723 & 0.4482 \\
\hline $2 \%$ Income Tax & 6.2000 & 7.5978 & 1.5228 & 4.6513 & 2.5537 & 0.0723 & 0.4481 \\
\hline $1 \%$ Income Tax & 6.1000 & 7.4852 & 1.5203 & 4.5711 & 2.5202 & 0.0718 & 0.4397 \\
\hline $0 \%$ Income Tax & 6.1000 & 7.4806 & 1.5100 & 4.5774 & 2.5218 & 0.0717 & 0.4371 \\
\hline
\end{tabular}

*Note: All dollar values are scaled by $\$ 10000$. Property values are expressed as annual payments on a fixed rate mortgage at $7 \%$ interest. Property tax rates may appear high because they are tax rates on these annual payments, not on the full value of the property.

with the median voter's best interest at heart would choose to set high property tax rates. ${ }^{31}$

These results indicate that the uniform use of local income taxes cannot be part of an unconstrained equilibrium in this setting because, when all other communities set property tax rates to zero, it is each planner's best response to lower income taxes and allow voters to raise property taxes

31 Again, this is not reflected Table 5 but calculated separately by comparing before and after reform utilities for agents originally residing in community 2 . 
regardless of what his objective function is. The combined impact of the results in Tables 4 and 5 seems to be that keeping income tax rates close to zero is a dominant strategy for local planners regardless of their objective function; that is, regardless of what tax systems prevail in other communities, it is always in each individual planner's best interest to keep income out of local tax bases. This offers a plausible general equilibrium explanation for the dominant use of property as a local tax base as well as the institutional structure of allowing myopic voters to determine property tax rates and planners to set income taxes.

\section{The Simultaneous Introduction of Income into Local Tax Bases}

Since the simulation results thus far have been driven mainly by migration effects resulting from local tax reforms, it seems reasonable to assume that the conclusions would change dramatically if migration could be prevented. One way to prevent such interjurisdictional migrations is for local governments to impose large moving costs (exit taxes). Freedom of mobility, however, is so fundamental to most democratic societies that its impairment is likely to be a difficult task for community planners. A second way to prevent migrations is for planners to collude and introduce income into local tax bases simultaneously which would eliminate the incentives of agents to move in order to evade the local tax reform. The only remaining problem is that collusion of this kind displays all the self-destructive properties of collusion within cartels. In particular, since our previous results indicate that the local property tax is a dominant local tax strategy for planners to employ, any agreement to collude would not be self-enforcing. Thus, if substantial local opposition to the property tax arises, planners find themselves in a classic prisoner's dilemma in which they would agree to enter a collusive agreement to simultaneously introduce income taxes, but all participants to the agreement have an incentive to violate it.

Collusion between communities is therefore not feasible unless an outside enforcer can be found to police the agreement. The ideal candidate for such an enforcement role is the state government which can simply impose a uniform income tax on the residents of the state and then pass the revenues back to local planners in the form of intergovernmental grants. 32

32 This is precisely the institution commonly observed in the US, although a deeper political model of the state would be required to explain redistributive elements of these institutions. 
TABLE 6

\begin{tabular}{|c|c|c|c|c|c|c|c|}
\hline \multicolumn{8}{|c|}{$\begin{array}{l}\text { General Equilibrium Effects from a Simultaneous } \\
\text { Introduction of a Local Income Tax in all Communities* }\end{array}$} \\
\hline & Income & Wealth & Property & Consump. & Utility & Prop. Tax & LPG \\
\hline \multicolumn{8}{|l|}{ Community 1} \\
\hline $\begin{array}{l}0 \% \text { Income } \mathrm{Tax} \\
1 \% \text { Income Tax } \\
2 \% \text { Income Tax } \\
3 \% \text { Income Tax } \\
4 \% \text { Income Tax } \\
5 \% \text { Income } \mathrm{Tax} \\
6 \% \text { Income } \mathrm{Tax}\end{array}$ & $\begin{array}{l}3.3000 \\
3.4000 \\
3.4000 \\
3.2840 \\
3.3000 \\
3.3000 \\
3.3000\end{array}$ & $\begin{array}{l}4.3900 \\
4.3124 \\
4.2443 \\
4.2865 \\
4.2963 \\
4.2805 \\
4.2226\end{array}$ & $\begin{array}{l}0.6550 \\
0.6526 \\
0.6477 \\
0.6234 \\
0.6003 \\
0.5844 \\
0.5479\end{array}$ & $\begin{array}{l}2.9462 \\
2.8560 \\
2.8002 \\
2.8839 \\
2.9073 \\
2.8982 \\
2.8690\end{array}$ & $\begin{array}{l}1.5920 \\
1.5618 \\
1.5405 \\
1.5693 \\
1.5799 \\
1.5799 \\
1.5725\end{array}$ & $\begin{array}{l}0.4247 \\
0.3608 \\
0.3016 \\
0.2618 \\
0.2345 \\
0.1986 \\
0.1618\end{array}$ & $\begin{array}{l}0.2782 \\
0.2695 \\
0.2634 \\
0.2617 \\
0.2727 \\
0.2811 \\
0.2866\end{array}$ \\
\hline \multicolumn{8}{|l|}{ Community 2} \\
\hline $\begin{array}{l}0 \% \text { Income Tax } \\
1 \% \text { Income Tax } \\
2 \% \text { Income Tax } \\
3 \% \text { Income Tax } \\
4 \% \text { Income Tax } \\
5 \% \text { Income Tax } \\
6 \% \text { Income Tax }\end{array}$ & $\begin{array}{l}5.2000 \\
5.5000 \\
5.5100 \\
5.5123 \\
5.3000 \\
5.3500 \\
5.4748\end{array}$ & $\begin{array}{l}6.3027 \\
6.4307 \\
6.4122 \\
6.4362 \\
6.3703 \\
6.3952 \\
6.4227\end{array}$ & $\begin{array}{l}1.0250 \\
1.0323 \\
1.0335 \\
1.0323 \\
1.0311 \\
1.0299 \\
1.0378\end{array}$ & $\begin{array}{l}4.0753 \\
4.1255 \\
4.1324 \\
4.1052 \\
4.0675 \\
4.0860 \\
4.0818\end{array}$ & $\begin{array}{l}2.1449 \\
2.1699 \\
2.1739 \\
2.1709 \\
2.1596 \\
2.1661 \\
2.1661\end{array}$ & $\begin{array}{l}0.3880 \\
0.3423 \\
0.2993 \\
0.2565 \\
0.2240 \\
0.1689 \\
0.1094\end{array}$ & $\begin{array}{l}0.3977 \\
0.4083 \\
0.4154 \\
0.4301 \\
0.4430 \\
0.4415 \\
0.4420\end{array}$ \\
\hline \multicolumn{8}{|l|}{ Community 3} \\
\hline $\begin{array}{l}0 \% \text { Income Tax } \\
1 \% \text { Income Tax } \\
2 \% \text { Income Tax } \\
3 \% \text { Income Tax } \\
4 \% \text { Income Tax } \\
5 \% \text { Income Tax } \\
6 \% \text { Income Tax }\end{array}$ & $\begin{array}{l}6.5000 \\
6.1000 \\
6.3000 \\
6.2038 \\
6.4000 \\
6.3500 \\
6.2252\end{array}$ & $\begin{array}{l}7.5573 \\
7.5178 \\
7.6045 \\
7.5188 \\
7.5688 \\
7.5633 \\
7.5615\end{array}$ & $\begin{array}{l}1.5700 \\
1.5761 \\
1.5797 \\
1.5858 \\
1.6041 \\
1.6247 \\
1.6211\end{array}$ & $\begin{array}{l}4.5568 \\
4.5602 \\
4.6152 \\
4.5337 \\
4.5422 \\
4.5222 \\
4.5414\end{array}$ & $\begin{array}{l}2.5093 \\
2.5150 \\
2.5321 \\
2.5063 \\
2.5068 \\
2.5006 \\
2.5078\end{array}$ & $\begin{array}{l}0.2706 \\
0.2295 \\
0.1873 \\
0.1485 \\
0.1034 \\
0.0643 \\
0.0286\end{array}$ & $\begin{array}{l}0.4248 \\
0.4227 \\
0.4219 \\
0.4217 \\
0.4218 \\
0.4219 \\
0.4199\end{array}$ \\
\hline
\end{tabular}

*Note: All dollar values are scaled by $\$ 10000$. Property values are expressed as annual payments on a fixed rate mortgage at $7 \%$ interest. Property tax rates may appear high because they are tax rates on these annual payments, not on the full value of the property.

Table 6 illustrates the feasibility of such an arrangement by reporting the effects of a simultaneous introduction of an income tax in all communities. Note that there are now virtually no consistent interjurisdictional migration effects while changes in other variables are small and often lack any sort of trend. The notable exception to this is the change in property values (and its impact on wealth levels), as well as the increase in the LPG level in community 2.33 The divergence in property values occurs

33 The increase in the LPG level in community 2 is what is known in the literature as "flypaper effects." The flypaper effect is simply the empirical observation that increases in local government income have a greater impact on LPG levels than increases in personal income. In our case, the state government simply raises income tax revenues, hands them to the local government as a grant and achieves increases in LPGs despite the fact that the entire grant was raised from within the community. 
as the equilibrium is moving from having LPGs exclusively funded through property taxation (as in the first benchmark equilibrium) to uniformly increasing reliance on local income tax revenues (as in the second benchmark equilibrium). The resulting divergence of property values reflect the some of the same characteristic as the latter equilibrium of Table 3. A similar divergence of other variables such as income is not observed because, rather than starting with property tax rates exogenously set to zero and agents residing at initial endowment points, we begin here in an equilibrium in which agents have already separated based on the exclusive use of property taxes, and because of the uniform income tax rates (which eliminate the incentives to migrate). Rather than inducing migrations that cause community income divergence, property values adjust.

While Table 6 gives no reason why local planners might wish to agree to simultaneously raise local income taxes, it provides no reason to believe that general equilibrium effects will create sufficient barriers to keep them from doing so. In light of this, if the property tax is perceived as being inherently unfair in its administration and public opposition to it is sufficiently large, colluding in this way (i.e. having states impose a system of income taxes and grants) may represent a painless way for community planners to respond to local demands without significantly altering their own utility. In fact, in the presence of such voter dissatisfaction with the property tax, a state enforced agreement is the only feasible way for planners to escape the prisoner's dilemma described above.

\section{Conclusion}

In this paper we have attempted to explain the widespread use of local property taxation as well as the evolution of state grant systems by modelling the mix of property and income in local tax bases as resulting from a maximization problem undertaken by a community planner. We have provided some guiding intuition as well as evidence from calibrated general equilibrium simulations that indicate that property taxation may be a dominant local tax strategy when community planners take migration and general equilibrium price changes into account. Furthermore, we have argued that local dissatisfaction with property taxation can be overcome most easily through the use of state grant systems that allow for the uniform introduction of income into local tax bases while avoiding migration effects. These conclusions are shown to hold under a variety of different objective functions for community planners. In the absence of state intervention, informed planners are therefore constrained by the general 
equilibrium forces in their local public good economy to employ a tax system that myopic voters may or may not desire. Even in the absence of informed planners, however, the forces described in this paper could be argued to bring about the evolution of local tax systems that tax property but not income. This line of argument is not pursued here but may prove fruitful in future research.

When communities deviate from the dominant property tax strategy, the model in this paper predicts a negative impact on that community's income, property values, wealth and local public good levels. Anecdotal evidence from metropolitan areas in the United States lends some support to this hypothesis. It would therefore be an interesting empirical avenue for future research to investigate the extent to which the decline of American cities over the last few decades is attributable to the introduction of income taxes and the resulting migration effects in those cities.

It should be noted that all the results in this paper rely on the mobility of local residents. As the costs to mobility rise, the significance of the conclusions in this paper falls. In many states of the US, for example, metropolitan areas are composed of numerous school districts any one of which could be chosen as a place of residence by a family whose breadwinner works in that area. Because mobility between any two communities is less costly the closer these communities are, the cost of interjurisdictional mobility within this metropolitan area is thus often close to the cost of intrajurisdictional mobility. But, while the arguments set forth here may explain the structure of local public finance in many US states that have hundreds of local communities and school districts, they lose their predictive power when we attempt to explain the tax systems in state or national governments. States in the US as well as countries in Western Europe are, perhaps, large enough and the legal and cultural barriers to mobility high enough for governments to be able to use income taxation without subjecting themselves to the adverse migration effects described in this paper. As these barriers come down, however, we may observe changes in state and national tax systems.

Finally, the computable GE model of local public finance developed here represents a potentially powerful tool for policy analysis. For example, the general efficiency and equity consequences of large scale changes in school funding such as those recently undertaken in Michigan could be predicted through a model of this type. Furthermore, the model's structure can easily be adapted to study policy questions arising in emerging federations such as South Africa and the former East block countries, as well as to investigate more traditional concerns over spillovers and interjurisdictional redistribution. 


\section{References}

Bogart, W. T. (1990): Essays on Intergovernmental Grants, Property Taxation and Housing Markets, Ph.D. dissertation, Princeton University.

Bucovetsky, S. (1991): “Asymmetric Tax Competition,” Journal of Urban Economics 30, 167-181.

Bucovetsky, S. and J. D. Wilson (1991): "Tax Competition with Two Tax Instruments," Regional Science and Urban Economics 21, 333-350.

Coates, D. (1993): "Property Tax Competition in a Repeated Game," Regional Science and Urban Economics 23, 111 119.

Courant, P. N., E. Gramlich and D. Rubinfeld (1980): "Why Voters Support Tax Limitation Amendments: The Michigan Case," National Tax Journal 33, 1-20.

De Tray, D. and J. Fernandez (1986): "Distributional Impacts of the Property Tax Revolt," National Tax Journal 39, 435-450.

Dunz, K. (1985): "Existence of Equilibrium with Local Public Goods and Houses," SUNY-Albany Department of Economics Discussion Paper \#201.

Epple, D., R. Filimon and T. Romer. (1993): "Existence of Voting and Housing Equilibrium in a System of Communities with Property Taxes," Regional Science and Urban Economics 23, 585-610.

Gordon, R. (1986): "Taxation of Investment and Savings in a World Economy," American Economic Review, 10861102.

Gramlich, E. (1977): "Intergovernmental Grants: A Review of the Empirical Literature," in The Political Economy of Fiscal Federalism (W. Oates, Editor), Lexington Books, 219-239.

Hanushek, E. and J. Quigley (1978): "An Explicit Model of Intrametropolitan Mobility," Land Economics, 54, 411 428.

Internal Revenue Service, Statistics of Income Division (1987): 1987 Individual Income Tax Model.

Ioannides, Y. M. (1987): "Residential Mobility and Housing Tenure Choice," Regional Science and Urban Economics, $17,265-288$.

Krelove, R. (1993): "The Persistence and Inefficiency of Property Tax Finance of Local Public Expenditures," Journal of Public Economics 51, 415-435.

Nechyba, T. (1994a): "Existence of Equilibrium and Stratification in Local and Hierarchical Tiebout Economies with Property Taxes and Voting," mimio, Stanford University.

Nechyba, T. (1994b): Fiscal Federalism and Local Public Finance: A General Equilibrium Approach with Voting, unpublished Ph.D. dissertation, University of Rochester.

New Jersey Associates (1988): New Jersey Municipal Data Book, 1988 Edition, Montclair, NJ.

Pogodzinski, J.M. and D. L. Sjoquist (1993): "Alternative Tax Regimes in a Local Public Good Economy," Journal of Public Economics 50, 115-141.

Shepsle, K. (1979): "Institutional Arrangements and Equilibrium in Multidimensional Voting Models," American Journal of Political Science 23, 27-59.

State of New Jersey (1988): Annual Report of the Division of Taxation in the Department of Treasury for the Fiscal Year 1987, Trenton, NJ.

Strauss, R. P. (1993): "Reforming School Finance in Illinois: Some Observations on Principles, Practicalities, and Politics," State Tax Notes 5, no. 7, 351-360. 
Westhoff, F. (1977): "Existence of Equilibria in Economies with a Local Public Good," Journal of Economic Theory, $14,84-112$.

Wildasin, D. E. (1993): "Fiscal Competition and Interindustry Trade," Regional Science and Urban Economics 23, 369 399.

Wildasin, D. E. (1991): "Some Rudimentary 'Duopolity' Theory," Regional Science and Urban Economics 21, 393421.

Wildasin, D. E. (1989): "Interjurisdictional Capital Mobility: Fiscal Externality and a Corrective Subsidy," Journal of Urban Economics 25, 193-212.

Wildasin, D. E. (1988): "Nash Equilibrium in Models of Fiscal Competition," Journal of Public Economics 35, 229 240.

Wilson, J. D. (1994): "Mobile Labor in a Tax Competition Model," mimio, Indiana University.

Wilson, J. D. (1987): "Trade, Capital Mobility and Tax Competition," Journal of Political Economy 95, 710-736.

Wilson, J.D. (1986): “A Theory of Interregional Tax Competition," Journal of Urban Economics 19, 296-315.

Zodrow, G. R. and P. Mieszkowski (1986): "Pigou, Tiebout, Property Taxation, and the Underprovision of Local Public Goods," Journal of Urban Economics 19, 350-370. 